Volume 13 Number 3, July-September 2019: pp. 231-240. Copyright (c) 2019 FIAT JUSTISIA. Faculty of Law, Lampung University, Bandarlampung, Lampung, Indonesia. ISSN: 1978-5186 | e-ISSN: 2477-6238. Open Access: http://jurnal.fh.unila.ac.id/index.php/fiat

Fiat Justisia is licensed under a Creative Commons Attribution 4.0 International License, which permits unrestricted use, distribution, and reproduction in any medium, provided the original work is properly cited.

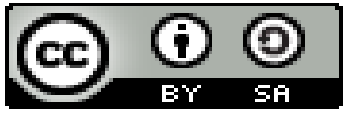

\title{
Separatist Creditors vs. Preferred Creditors Rights in the Bankruptcy Case Based on the Decision of Constitutional Court of 2013
}

\author{
Rilda Murniati \\ Universitas Lampung, Indonesia \\ rilda_murniati@ymail.com \\ Desma Cahya Selvya \\ Universitas Lampung, Indonesia \\ dcahyaselvya@gmail.com
}

\begin{abstract}
Workers are preferred creditors whose payment must take precedence in the bankruptcy of the company. Problems in practice occur in the company's assets as collateral for debt to separatist creditors so that workers' rights are ruled out. Therefore, workers submit applications for judicial review of the Bankruptcy Law and Labor Law. This study is normative research using primary legal materials, namely laws and case study decisions that are analysed qualitatively. The results of the study and discussion determined that the Bankruptcy Law and the Labor Law regulate the same as the legal status of workers as preferred creditors who are entitled to prioritize payment in the distribution of bankrupt assets strengthened by the results of a judicial review in Decision of the Constitutional Court Number 67/PUUXI/2013 The right of workers to wages is prioritized and calculated from collateral objects which are the rights of separatist creditors. For this reason, curators with authority must share the right of separatist creditors and preferred creditors with the principle of balance and justice so that all the assets of a bankrupt company can pay off the debts of its creditors.
\end{abstract}

Keywords: Workers, Preferred Creditors, Separatist Creditors, Constitutional Court, Decision Number 67/PUU-XI/2013 
How to Cite: Rilda Murniati, Desma Cahya Selvya, "Separatist Creditors vs. Preferred Creditors Rights in the Bankruptcy Case Based on the Decision of Constitutional Court of 2013", Fiat Justisia, 13 (3), (2019).

\section{DOI:10.25041/fiatjustisia.v13no3.1616}

\section{A. Introduction}

The company is one of the economic actors whose business activities are regulated by law. Business activities of the company can run continuously if supported by capital adequacy. Capital obtained by the company can be obtained from the owner of the company itself (entrepreneur) or other parties. If the company is unable to get its capital requirements, the company will make loans to bank and non-bank financial institutions with a guarantee. Provision of loans from financial institutions is based on trust in guarantees that can be given by the company to repay the loan on time.

Companies in carrying out their business activities need help from workers. If the employer runs the company as the owner of the company, the worker has a working relationship with the entrepreneur. However, if the employer orders other people to run the company based on a power of attorney, then the worker has a working relationship with the leader of the company. The more advanced a company is, the more workers company will need to run the company's business activities. ${ }^{1}$

Good corporate management will have an impact on the progress of the company so that the company can return the loan on time. However, when a company experiences a setback, it can result in a loan that cannot be returned on time so that the creditor can file a bankruptcy application. The bankruptcy petition against the company can be granted by the Judge of the Commercial Court with simple proof requirements as stipulated in Article 2 Paragraph (1) of Law Number 37 of 2004 on the Bankruptcy and Delay of Debt Payments (Bankruptcy Law) which has two debts (creditors) and one of the debts is due to be billed. ${ }^{2}$ The decision of the company's bankruptcy statement resulted in all the assets of the bankrupt company entering into the general confiscation to pay off the debts of the creditors who were under the authority of the curator, and the bankrupt debtor was in bankruptcy.

The bankruptcy of the company resulted in the worker being a preferred creditor of bankrupt assets, while the lender was a separatist creditor. The position of workers as preferred creditors is regulated in the Bankruptcy Law

\footnotetext{
${ }^{1}$ Abdulkadir Muhammad, Hukum Perusahaan Indonesia, Bandung: Citra Adity Bhakti, (2010), p. 25.

${ }^{2}$ Lindati Dwiatin dan Rilda Murniati, Hukum Kepailitan: Kajian Teoritis Kepailitan Perusahaan dan Akibat Hukumnya, Bandar Lampung: Zam-Zam Tower, (2017), p. 33.
} 
and the Labor Law which stipulates that payment of workers' wages must take precedence in the distribution of bankrupt assets. The problem that occurs is that if all bankrupt assets are collateral belonging to a separatist creditor, the workers do not obtain his rights in the distribution of bankrupt assets. The rights of separatist creditors are also strengthened by the results of the judicial review of the Bankruptcy Law in the Decision of the Constitutional Court Number 18/PUU-VI/2008, and these rights can be exercised as if there was no bankruptcy. However, workers as preferential creditors must always prioritise their rights as guaranteed by legal certainty stipulated in Article 95 Paragraph (4) of Law Number 13 Year 2003 concerning Labor (from now on referred to as the Labor Law). The legal facts, in the distribution of the bankruptcy of the company by the Curator, workers who do not obtain their rights as stipulated in the provisions of the law so that a request for a judicial review of the Labor Law is made to the Constitutional Court.

Judicial review requests are submitted to obtain clarity on the rights of workers as preferred creditors in the distribution of bankrupt assets. Explanation of Article 95 Paragraph (4) of the Labor Law states that the payment of workers' wages must take precedence over other creditors. The Constitutional Justice Board partially grants judicial review requests submitted by workers. The Constitutional Justices in the Decision of the Constitutional Court Number 67/PUU-XI/2013 give consideration. Namely, the payment of workers' wages must take precedence. It means that workers' preferential rights, namely the payment of their wages in the distribution of bankrupt assets, result in the position of workers as preferred creditors being above separatist creditors.

Based on the description of the background stated above, the main problems in this study are as follows: What are the rights of workers as preferred creditors in corporate bankruptcy? How is the application of preferred creditor rights in bankruptcy companies based on the Decision of the Constitutional Court Number 67/PUU-X/2013?

\section{B. Research Methods}

This type of research is normative research. Normative legal research examines the implementation or implementation of normative legal provisions (statutory regulations). This study examines the contents of the Decision of the Constitutional Court Number 67/PUU-XI/ 2013. The type of research used in this study is descriptive, namely describing in full and in detail, the rights of workers who are domiciled as preferred creditors to bankrupt debtor assets. The approach to the problem used is applied normatively with the type of case study. The normative data used are sourced from laws and decisions. For this reason, data collection is done by literature study and document study and then processed and analysed qualitatively. 
This type of research is normative research with descriptive research type. The approach to the problem used is applied normatively with the type of case study. The normative data used are sourced from laws and decisions. For this reason, data collection is done by literature study and document study and then processed and analysed qualitatively.

\section{Discussion}

\section{Worker Rights as Preferred Creditors in Bankruptcy of the Company}

In bankruptcy practices, demands for rights that occur against the curator and cause problems in the distribution of bankrupt assets are often carried out by separatist creditors (holders of collateral rights) and preferred creditors (workers). Distribution of bankrupt assets carried out by the curator and objections or objections made by workers because the payment is prioritised by separatist creditors as holders of collateral rights. The rights of separatist creditors to guarantees are regulated under the Bankruptcy Law, and their legal status is strengthened through the Constitutional Court Decision Number 18/PUU-VI/2008 in the practice of applying the distribution of bankrupt company assets.

Based on the provisions of Article 55 Paragraph (1) the Bankruptcy Law states that separatist creditors have the right to execute their collateral as if there was no bankruptcy. The problem that occurs is that if all bankrupt assets are collateral belonging to a separatist creditor, the worker as the preferred creditor does not obtain his rights in the distribution of bankrupt assets. Whereas explicitly in the Act of Headquarters and Labor Law put workers as creditors who have special rights.

The curator's actions in distributing bankrupt assets to workers are regulated in the Bankruptcy Law and the Labor Law. Article 39 Paragraph (1) of the Bankruptcy Law determines two possibilities occur to the fate of workers if the company is declared bankrupt. The first possibility is that workers can continue to run their jobs in companies that have been declared bankrupt. It can be done because based on Article 104 of the Bankruptcy Law, the curator can run a bankrupt company with a temporary creditor committee agreement or with the permission of the Supervisory Judge with the consideration that the business activities that continue to provide benefits to bankrupt assets. The second possibility is that workers are subject to termination of employment (PHK). Based on Article 39 Paragraph (1) of the Bankruptcy Law, a layoff can be carried out by the curator if based on the consideration that the bankrupt company can no longer be executed because it does not provide benefits.

During the bankruptcy process, the curator is guided by the Labor Law in carrying out provisions regarding layoffs and determining the rights that 
can be obtained by workers in the distribution of bankrupt assets. Article 165 of the Labor Law states that after a layoff due to a bankrupt company, workers are entitled to severance pay in the amount of 1 (one) time in Article 156 Paragraph (2) of the Labor Law, a work period of 1 (one) time for Article 156 Paragraph ( 3) Labor Law and compensation for rights in accordance with Article 156 Paragraph (4) of the Labor Law.

Based on Article 39 Paragraph (2) of the Bankruptcy Law which states that from the date the decision on bankruptcy statement is pronounced, the wages owed before and after the verdict of the bankruptcy statement are stated as bankrupt assets. Furthermore, in Article 95, Paragraph (4) of the Manpower Law states that when a company is declared bankrupt, then the wages and other rights of the worker constitute the debt that must be prioritised. Explanation of the meaning of the prioritisation of payment is that the wages of workers must be paid in advance of other debts.

\section{Application of Preferred Creditors' Rights in Corporate Bankruptcy Based on Constitutional Court Decision Number 67/PUU-XI/2013}

Workers submit a judicial review application represented by 9 (nine) employees of Pertamina Company who are members of the All Indonesia Pertamina Workers Union (SPPSI) (referred to as the applicants) and registered at the Registrar's Office of the Constitutional Court on June 27, 2013, with case registers number 67/PUU-VI/2013. The reason for the request for a judicial review of the Labor Law is the existence of workers' constitutional rights guaranteed by the 1945 Constitution, but these rights cannot be fulfilled accordingly. Workers request clarity of legal status on their rights to prioritise payments in the distribution of bankrupt assets as stipulated in Article 95 Paragraph (4) of the Labor Law.

According to the workers, there is no clear interpretation of Article 95 Paragraph (4) of the Labor Law, namely that payment is prioritized as wages and other rights workers must be paid in advance of other debts. The phrase "prioritised payment" has caused multiple interpretations. As a result, workers are placed in a weak position and are not aligned with separatist creditors whose payments take precedence if the company experiences bankruptcy. Therefore, workers ask for clarity of interpretation "prioritise payment" in the distribution of bankrupt assets.

The unclear interpretation of Article 95 Paragraph 4 of the Labor Law, especially in the "payment precedence" clause has the potential to create legal uncertainty and violation of workers' rights and cause injustice to workers because the repayment mechanism for paying bankruptcy debts is based on priority levels namely separatist creditors ( collateral, fiduciary and other 
material rights holders), bankruptcy fees, fee curators, preferred creditors (workers) and the latter are concurrent creditors. ${ }^{3}$

The Constitutional Court Justices in its consideration, distinguish various aspects between entrepreneurs and workers, as follows:

a. The entrepreneur's socio-economic position is higher than the worker (legal subject aspect).

Pawn, mortgage and fiduciary agreements and other dependent agreements are agreements made by legal subjects, namely entrepreneurs or investors. Conversely, work agreements are agreements made by employers and workers. Socially and economically, employers and workers are not equal. Entrepreneurs are certainly stronger and socioeconomic higher than workers. Therefore, workers' rights are guaranteed by the 1945 Constitution and the Manpower Act to guarantee the protection of workers' rights.

b. Entrepreneurs make property as collateral while workers guarantee their expertise (object aspects).

From the aspect of the object of the pawn agreement, mortgages, fiduciary and other dependent agreements that become the object is property. While the work agreement that becomes the object is labour, skills or services in return in the form of wages to fulfil the basic needs of life for workers and their families, so that the two aspects of this object have fundamental differences, namely property and human.

c. Entrepreneur risk getting profits or loss, but workers get wages in return for doing work (aspects of risk).

Risks for employers are part of the things that are reasonable in managing their business, in addition to profits or loss. Therefore, the risk is a matter that becomes the scope of consideration when doing business, not space in the job. For wage workers, it is a means to meet the needs of workers and their families, so that it becomes inappropriate if wages are ranked lower if compared with risk.

The Constitutional Court Justices in legal considerations as the Constitutional Court Decision Number 67/PUU-XI/2013 states that in the event of bankruptcy now the wages of workers have a higher position than

\footnotetext{
${ }^{3}$ Jekson Firdaus Sitorus dan Heriyanto, Analisis Yuridis Kedudukan Upah Buruh Pasca Putusan Mahkamah Konstitusi Nomor 67/PUU-XI/2013 Dikaitkan dengan Kreditor Pemegang Jaminan Kebendaan dalam Hal Terjadi Kepailitan, Yogyakarta: Magister Hukum Bisnis Universitas Gadjah Mada, (2018), p. 1.
} 
separatist creditors. However, this only applies to workers' wages, regarding workers' bills in the form of other rights such as severance pay, award money and compensation rights, separatist creditors still have a higher position.

The wages of workers are constitutionally guaranteed in Article 28D Paragraph (2) of the 1945 Constitution. While other rights of workers are not, so it is natural that concerning the payment of other rights workers are ranked below separatist creditors. Regarding obligations to the state, it is only natural if the rank is after the wages of workers, because the state has other sources of financing, while for workers wages are the only source of income.

Payment of outstanding employee wages takes precedence over all types of creditors including separatist creditor bills, bankruptcy fees, curator fees and claims against the state whereas the payment of other workers' rights takes precedence over all types of bills including bankruptcy fees, curator fees and claims against the state except for bills of separatist creditors.

Based on the above considerations, the Constitutional Court Justices in the Constitutional Court Decision Number 67 / PUU-XI / 2013 granted part of the petition of the petitioners regarding payment of workers' wages which must be prioritised, but other rights of workers paid after payment of accounts of separatist creditors.

The decision of the Constitutional Court is final which means that the decision of the Constitutional Court legally has permanent legal force since it was pronounced and there is no legal remedy that can be taken against the verdict (final and binding). ${ }^{4}$ Accordingly, the regulation regarding the position of separatist creditors and workers must go according to the provisions of the Constitutional Court Decision, including regarding the regulation of wages for workers who must be prioritised in the distribution of bankrupt assets. The decision of the Constitutional Court Number 67/PUU-XI/2013 determines that rights that must take precedence in the order of the distribution of bankrupt assets by the curator and bankruptcy decisions are the wages of workers, separatist creditors, other workers' rights and obligations to the state.

The legal basis for workers' wages as preferred creditor bills in the bankruptcy process, which is based on the Bankruptcy Law and Labor Law, is based on the principle of lex posteriori derogat legi priori (on equal regulations, newer regulations override the regulations prior). ${ }^{5}$ Thus, the

\footnotetext{
${ }^{4}$ Riyanda Kiransyah, Analisis Kedudukan Kreditor Separatis terkait Upah Pekerja dari Debitor Pailit (Studi Kasus Putusan Mahkamah Konstitusi Nomor 67/PUU-XI/2013), Medan: Fakultas Hukum Universitas Sumatra Utara, (2017), p. 15.

5 Dicki Nelson, Kedudukan Upah Buruh dalam Kepailitan Pasca Putusan Mahkamah Konstitusi Nomor 67/PUU-XI/2013 dalam Kajian Undang-Undang Nomor 37 Tahun 2004 Tentang Kepailitan dan Penundaan Kewajiban Pembayaran Utang,Bandung: Universitas Padjajaran, (2013), p. 8.
} 
provisions of the Constitutional Court Decision Number 67/PUU-XI/2013 whose position must be prioritized in the distribution of bankrupt assets as a newer decision can override the Constitutional Court Decision Number 18/PUU-VI/2008 which positions separatist creditors to take precedence payment for the distribution of bankrupt assets.

The implication of the application of the Constitutional Court Decision is the reduction in the rights of separatist creditors to their collateral because the proceeds from the sale of collateral are used to pay workers' wages. The actions of these curators often get objections from separatist creditors. Complaints resolved by separatist creditors were filed through legal remedies for the procedure as a rebuttal to the list of bankrupt assets distributed by the curator to the Commercial Court. Reason for requesting renvoi procedure from separatist creditors because they feel their rights are harmed by reducing their collateral where the Bankruptcy Law protects the right.

In principle, the distribution of bankrupt assets must be able to pay all debts held by bankrupt debtors. Therefore, based on the Decision of the Constitutional Court Number, 67/PUU-XI/2013 separatist creditors must give up their reduced guarantee rights. It is in line with the legal objectives of balance and fairness in the distribution of bankrupt assets and must be by the level of position of creditors in the prevailing laws and regulations, especially for workers as preferred creditors whose rights must be prioritized even though all bankrupt assets become debt collateral to separatist creditors. Thus, it is reasonable for the Constitutional Court to justify the preferential rights of workers in the distribution of bankrupt assets from objects guaranteed by separatist creditors to pay off the wages of workers' wages which are the right to life and livelihood as human rights.

\section{Conclusion}

Based on the description in the discussion that has been presented, it can be concluded:

1. Bankruptcy Law and the Labor Law regulate explicitly and equally regarding the status of legal workers as preferred creditors. The preferential rights of workers in the distribution of bankrupt assets are prioritized. The workers' rights that should be obtained by workers in practice are ruled out because there are separatist creditors who have full and executorial rights to collateral objects which are bankrupt assets. The practice of dividing workers' rights is excluded from separatist creditors, so it is reasonable for the law to apply for a judicial review of the Labor Law which calls for clarity of the legal status of workers as preferred creditors in the bankruptcy of the company. 
2. The Constitutional Court Justices in its decision Number 67/PUU$\mathrm{XI} / 2013$ pay wages provide legal considerations that strengthen the employment of workers is preferential rights whose payment must be prioritized in the distribution of bankrupt assets. Obligations for wages of workers in the company must be paid in full and take precedence when the company is declared bankrupt is a human right that can be taken from the part of bankrupt assets which are the rights of separatist creditors. For this reason, separatist creditors must accept the reduction of their security rights by the principles of justice and balance and based on the principle of lex posteriori derogat legi priori (in equal laws and regulations, newer regulations override old regulations). Thus, the Constitutional Court Decision Number 67/PUU-XI/2013 is the undisputed justification for the curator in the bankruptcy of the company so that the Commercial Court must reject all requests for objections (renvoi procedures) by separatist creditors on the distribution of property by the curator.

\section{A. Books}

\section{Bibliography}

Kiransyah, Riyanda. (2017). Analisis Kedudukan Kreditor Separatis terkait Upah Pekerja dari Debitor Pailit (Studi Kasus Putusan Mahkamah Konstitusi Nomor 67/PUU-XI/2013). Medan: Fakultas Hukum Universitas Sumatra Utara.

Lindati Dwiatin, Rilda Murniati. (2017). Hukum Kepailitan: Kajian Teoritis Kepailitan Perusahaan dan Akibat Hukumnya. Bandar Lampung: ZamZam Tower.

Muhammad, Abdulkadir. (2010). Hukum Perusahaan Indonesia. Bandung: Citra Adity Bhakti.

Nelson, Dicki. (2013). Kedudukan Upah Buruh dalam Kepailitan Pasca Putusan Mahkamah Konstitusi Nomor 67/PUU-XI/2013 dalam Kajian Undang-Undang Nomor 37 Tahun 2004 Tentang Kepailitan dan Penundaan Kewajiban Pembayaran Utang. Bandung: Universitas Padjajaran.

Sitorus, Jekson Firdaus dan Heriyanto. (2018). Analisis Yuridis Kedudukan Upah Buruh Pasca Putusan Mahkamah Konstitusi Nomor 67/PUUXI/2013 Dikaitkan dengan Kreditor Pemegang Jaminan Kebendaan dalam Hal Terjadi Kepailitan. Yogyakarta: Magister Hukum Bisnis Universitas Gadjah Mada.

\section{B. Legislation and Court Decisions}

Civil Code.

Law Number 13 of 2003 on the Labor.

Law Number 37 of 2004 on the Bankruptcy and Delay of Debt Payments. 
Constitutional Court Number 18/PUU-VI/2008.

Constitutional Court Number 67/PUU-XI/2013. 